\title{
NATIONALISM, NATION AWARENESS AND PAST IMAGINATION (A REFLECTIONS OF 65 YEAR HISTORY OF INDEPENDENT INDONESIA)
}

\begin{abstract}
Anzar Abdulah ${ }^{1}$
ABSTRACT

Allegations are often made ahead of the Proclamation of Independence of Indonesia, among others, is increasingly fading spirit of nationalism among the younger generation. Allegations are not necessarily true, but it has created a stigma in society. It needs to be clarified by outlining the background of the birth of nationalism and nationalism contextualization in conjunction with modern Indonesian society today. Nationalism is a long process of the dialectic between space, time and social groups, as well as the political process. Although there are its relation with the "birth", nationalism has always been the "birth process". Nationalism is a modern phenomenon, a notion of nationhood was born out of the equation the fate and suffering as a result of colonization, thus was born the solidarity for the nation rise up and liberate themselves from colonialism to freedom and independence. When the standards of nationalism were patriotism and physical struggle, like war of independence first, certainly has a point, that the nationalism awareness of youth today is fading. However, it should be explained that now no longer possible to perform a physical struggle full of heroism likethe past, but we now need is the social solidarity that can strengthen thesocial bonds of nationhood and Indonesiannessin chargeof this independence nature. This is what needs to be grown and developed because these values are now beginning to fade among the younger generation, the community and the nation's elite. Nationalism is not something static, but full of dynamics. Every era has different conditions and challenges, thus requiring a dynamic form of nationalism. This paper aims to analyze the relationship between nationalism, nation awareness, and the memories of the past as a reflection of history after 65 years of Indonesia Independent. Also as re-introspection ourselves as a nation, how far nationalism that has made us stronger in strengthening of Indonesianness nodes.
\end{abstract}

Key words : nationalism, nation awareness, past imagination, a reflection

1 Dr. Anzar Abdulah is a lecturer at the Faculty of Education and Teacher Training (FKIP) University of 45 Makassar. This Article has been reviewed by Dr. Agus Mulyana (Indonesia University of Education), M.Hum, Dr. Nana Supriatna, M.Ed (Indonesia University of Education), and Prof. Dadang Supardan, M.Pd ((Indonesia University of Education). For academic interest, the author can be contacted at E-mail: anzarabdullah91@yahoo.com 


\section{of history, 65 years of Indonesia Independent. \\ Introduction}

When it emerged a new awareness among young people of Indonesia in the period 1900-1928, about identity, emancipation, and the movement through education and organization, the seeds of awakening towards the idea of nationalism began to grow. The awareness should be as fast moving locomotive in the direction of "Indonesia is united" against cultural colonialism, economic, and political. But the rivalry of groups based on regionalism sentiment, ideology, and religion has slowed this process.

Nationalism or nationality discourses, was born not to carry the interest of a race, religion, or certain region, but for something that is imagined. This thesis expressed by political thinkers Benedick Anderson, decades ago in his now almost classical : Imagined Communities : Reflections on the Origin and Spread of Nationalism (1983). Nation is a community that "imagined", because in essence, they did not know each other. But, although they do not physically meet each other, nor even probably never heard of them each carefully, but in their minds there is an emotional connection as a nation that is "a spirit of brotherhood that stretches them horizontally". Later Anderson calling as "imagination project" which presupposes the existence of shared beliefs about fate, shared future and a camaraderie that extends to the side in the form of horizontal solidarity. This is what has allowed so many people are willing to sacrifice for the "sacred mission" for the sake of "shadowing" the nation's lofty ideals are believed to be together.

Therefore, Anderson's thesis presents the true of Indonesia as a pluralistic nation, and the recent storms prolonged crisis, Anderson's thesis seemed less important. Moreover, the actual fact we are not constantly torn nation of social conflict, because it fueled by the issue of SARA (Ethnic, Religion, Race, and Interclass). This fact would be a "nightmare" for the imagery that defined the entire nation's citizen about Indonesia. Because here, SARA act like oil on the flame of fire, how hot the flame was tortured and destroy many people on the stage of history.

Reflecting on the facts above, the awareness of pluralism will be value very important for this nation. Therefore, fostering a spirit of true pluralism is a necessity. For pluralism, as illustrated by Nurcholis Madjid (2004) is a genuine "engagement" of diversities within the bonds of civility.

This critical perspective presented, because in guarding the nation's journey to the front, now we're faced with at one time or a new era called globalization. An era where mobility and the human mind from day to day more and more space, time into the global system. Globalization as a fact of human life in this new century is a versatile interconnection crossing and no bulkhead (borderless) both in relations among nations, peoples, communities, until the intersection of interest between the areas of life, such as economics, politics, culture, religion, education and social. 


\section{Boedi Oetomo : Inspiration Towards Establishment of the Nation}

Non scholae discimus vitae sea (we learn not for school but for life). One piece of the story the way the family moved R. Soewadji from Bojonegoro to Madiun, East J ava in 1894, a strong impression in the minds of Soetomo. It was Soetomo 6 years old. In the book "Memories Doctor Soetomo, Sinar Harapan, J akarta (Onghokham, 1984), Soetomo write, I remember well that my parents, my father and mother, when moving to Madiun with a driving dogear. Somewhere in my journey with no known cause, dogear stopped, then dogear and his horse was pulled to the curb. My father crouched on the roadside, in honor of a Dutch ambtenaar who were there.

For Soetomo, that event called the incident that caused fear in him. Not surprisingly, when growingupand attended school in theSchool TotOpleiding Van Indisehe Artseschoal (STOVIA), when meet with doctors Wahidin Sudirohusudo, he told himself to move on the idea and effort doctor Wahidin, so that indigenous children can receive education through Studie Fonda (Kartodirdjo, 1992; Bakti, 2006).

For Soetomo, his meeting with Wahidin open his horizons, spread the ideals of the new world will as well as open new horizons of view, especially for teaching young people all over the land of J ava at that time. Together with his friends : M. Soelaiman, Gondo Soewarno, M. Goenawan Mangoen-koesoemo, R. Angka, M. Soeradji, Moh. Saleh, M. Soewarno, and RM Gombrek, they then established Boedi Oetomo (Hanifah, 1978).

For them, education and cultural development is a means to achieve equality with the Netherlands (Pringgodigdo, 1986). They encourage the intellect and culture are part of the identity as a nation. From there develops policies and insights on the nation grow.

Concerns about the position of citizens who experience injustice, is also felt by HOS Tjokroaminoto, one of the prominent leaders of Islam Union (Serikat Islam), H. Samanhoedi, as well as other Islamic union leaders are Abdoel Moeis, R. Goenawan. Goenawan as written by Deliar Noer in Islamic Modern Movement in Indonesia 1900-1942, LP3ES, J akarta (1980); for example, ever request that Indonesia's people justified to wear, so that when enter to the office of Dutch government, they can sit in a chair and not sit on floor. Why ? Because sitting cross-legged on the floor by using a shoe would be difficult. This has made the Dutch government stamped Tjokroaminoto as a dissident, and most strongly against the Netherlands as one of the leaders of Islamic Union (Savitri, 1985; Wild, et.al, 1986; Kahin, 1952). Even he is viewed by society at that time as Fair Queen who will free the country of Indonesia from all suffering (Korver, 1985). Deliar Noer writes, Tjokroaminoto attitude it is a form of protest against the measures of Dutch government considers that indigenous peoples are the nation's lower classes, after the Netherlands. Tjokroaminoto wants the nation also has a degree and an equal position with any nation. In a footnote in the article mentioned, Tjokroaminoto have the courage to sit in a chair, if met Dutch 
people or government officials. He told his superiors without subjecting the face, he sat in a chair by putting one foot on his other leg. Everything about the small but at that time was considered to be abstinence (Deliar Noer, 1980).

Attitudes and positions that are then also bring the organization of Islamic Union developed into a dynamic and respected organization of its time (Korver, 1985). Startingfromanorganization engagedineconomicdevelopment, theIslamic Union developed into an organization that oriented to the ideals of nationhood (Notosusanto, 1992), and the search for human rights which are created by the Lord, uphold and improve the lot of humanity degrees are still bad, even in the first National Congress in Bandung, in 1916, specifically Tjokroaminoto say "not unfair to see Indonesia as a milk-cow, which was given due to eating only milk. It is not appropriate to assume that the country as a place where people come with the intention of taking the result and at this time no longer be accounted for that people, especially indigenous people have no right to participate in political issues related to self-determination (Suhartono, 1994).

In Tjokroaminoto's hands, Islamic Union developed with four elements, namely that Islam teaches the idea of democracy and equality, Islam is the basis for character education of the people, as well as every citizen has the right to engage and participate in political life (G. Moedjanto, 1988 ; Dahm, 1987).

Not surprisingly, if the inclusive attitude and breadth of the concept of Tjokroaminoto's nationalism has become an inspiration to his students, such as Sukarno, the proclamair of Indonesia (Gani, 1973). This shows that how an idea has the power, on the other hand also shows about the quality of people who had theidea, at least the life experiences and Tjokroaminoto's alignments on the condition of citizens, has delivered inspiration and choices shape the nation's struggle for independence.

\section{Spirit of the Age}

Both Soetomo and the founder of Boedi Oetomo, as well Tjokroaminoto HOS and the figures of Islamic Union in the early days of national movements, those who live within the jurisdiction of the colonial government. Colonial government characterized by violence, oppression, and discrimination. Flow of information is of coursevery limited, so that movement of the world is not easy to know which can result in underdevelopment and smallness. But in reality, not so with Soetomo, he was inspired by the thought of Mahatma Gandhi. The flow of information and discussions that occur in a variety of mass media published in those days, as Renodhoemilah, who cared for by Wahidin be a means to keep abreast of the world. Similarly, relations with Douwees Dekker, editor of the newspaper “Bataviaasch Newsblad, open up horizons of STOVIA's students (Ricklefs, 1999; Poespoprodjo, 1986).

Past experience and encounter with the reality of times by youths, such as Soetomo, Goenawan Mangoekoesoemo, Soelaiman, Soeradji and others can in fact be a dialogue with the old figures, and the result is the orientation of the 
emergence of nationality as well as in the idea Tjokroaminoto and the founders of the idea of nationality as the time (Mulyana, 2008). They each by way and the choice to try build new currents, namely the ideals as a nation that is driven by the spirit of the age that continue raging.

\section{Nationalism Contextualization}

Starting at the time of the Roman Empire around 400 BC, the term of nationalism emerged with negative meaning, and only in the 18th century during the French revolution, nationalism has a positive meaning.

In Indonesia, the spirit of nationalism or love of the nation by our founding fathers with a very cleverly combined with dignity to fight the oppression of colonialism. Love of this nation in turn gave birth to a fighting spirit, selfsacrificing, sincere and selfless act for the glory of the nation. This attitude is not only the elite, but also rooted in the community.

Now the paradigm of nationalism seems to be interpreted as a love of unity and social solidarity which needs to be built in an effort to strengthen the spirit of nationalism, unity and social cohesion. Although the concept and its application differ between nationalism before the national movement, and when the present post-independence, nationalism that isuniversallynotborn naturally, but requires a touch and challenge to move forward. That's why momentum is happening in society when processed can strengthen a sense of nationalism. But let not the name of excessive nationalism, making us as Indonesian become a nation that look other nations as low nation and contemptible, which eventually gave birth to chauvinistic, which can make our nation as a nation that is not dignified, because being fond of attacking and annexing other countries (Committee of The book 100 Years Agussalim, 1984; S. Truna, et.aI, 2002).

Now, when the concept of development began to experience a lot of distortion in practice, how we want to actualize nationalism insights and our nationhood. The problem now is that many of us are often surprised by recent developments that seem to further strengthen globalism over nationalism, so there are fears, lest the oath of our youth today is a world of my fatherland, humanity is my nationhood, and English is my language (Kompas, 27 October 2008:6).

Youth pledge in the form of statement is important as the nation's collective memory, but is no less important is the substance and nature. Concerns about the erosion of nationality and love for Indonesianness in Indonesia's society today, may be an early warning and tendencies are dumped in the struggle of our founding fathers set up a republic which was named Indonesia.

Nationality or nationness and Indonesianess, recently became two of the more interesting concepts to be discussed in-depth, since for two reasons namely the political aspect, the concept of nationhood and Indonesianess, will remain relevant and should continue to be raised.

First, from a theoretical perspective, there are purposes that are ongoing in order to enrich the political discourse of this nation. Ernast Renan defines nationalism as fate equivalence, culture, enemy together. Without this concept, 
the impossible was born a national movement that is able to repel the colonizer and gave birth to a new country free and independent. In other words, nationalism should be interpreted as an inclusive and liberating force. This is precisely what later by Robert van Niel describes as a factor that cannot be separated, that the birth of Indonesian nationalism greatly influenced by the emergence of educated social groups in the archipelago of the earth in its time (Van Niel, 1984). Social class or educated new elite has opened the minds of young people on Western political ideas, including self-government and basic freedoms for the press, to unionized and to speech.

In Southeast Asia-Pastand Present (1989), historian Sar Desai from University of California at Los Angeles writes, "nationalism is undoubtedly the single most powerful element, dynamic, emotive (evocative), which has changed the political configuration in Asia and Africa in $20^{\text {th }}$ century". Nationalism is a response to imperialism and political and economic exploitation of the parties ruled.

According to Anthony D. Smith (1998) in the name of nationalism, it becomes a great nation state that is able to concentrate markets, administrative, taxation and education. His spirit is populist and democratic. Through nationalism, all forms and value system of feudalistic omitted. Nationalism, become source the birth of society sovereignty, and determination of their fate independently.

Secondly, from the perspective of Anthony D. Smith in his book "Nationalism and Modernism (1998) that theory of nationalism has developed from time to time, and depending on what approach is used. The view that the nation is a concrete entity, which is based on the historical background and social life of a homogeneous and united society, and reflects the major social and political actors in the modern world, in thirty years ago no longer seems untenable. Especially after the cold war ended, the empirical basis of getting lost. Soviet Union and Yugoslavia, has been shattered into small states. Many new states are born at the end of the $20^{\text {th }}$ century based on a consideration of ethnicity (ethno-nationalism) or religion factor (religio-nationalism) (Fukuyama, 1995).

Since entering the decade 1970s, the optimistic and realistic thoughts about the nations and nationalities began to melt. Despite differences of opinion arose amongscholars of history, anthropologyand sociology, they certainly acknowledge the power of psychological and sociological facts about the nation and the nation state. Therefore, required a new effort to build the nation through the means of communication, urbanization, education and political participation.

What is needed now by the Indonesian nation is how to make the process of national development can bring balance, equity and economic growth, to give flexibility to people's participation is not a monopoly by certain forces, support the communication process, and open public spaces, encouraging the emergence of a government well organized and very responsive, and accelerate emerge mature elite in politics with a purposes to welfare of citizens. But keep in mind that to achieve that goal is very important to remember and digest every historical event that happened in the past as a reflection of introspection for a nation in building awareness of its history (Frederick H., et.al, 1991).

New thinking about nationalism above indicated that the monopoly of 
interpretation and centralization understanding about should be replaced by the democratization of understanding substantially. Because nationalism is an imagined political communities, then there should be sharing of idea and even the socio political sharing between various communities of supporters. Without it all, then the existence of nationalism will be lost, especially large countries like Indonesia are very complex consisting of various ethnic groups, languages and customs vary. Therefore, it should be an equitable division between the various elements of the nation and the region became a necessity. In other words, nationalism of Indonesia can only be contextualized, if we all pay attention to the role of various local values, therein. By trusting the role of local values, it means we have rediscovered the "social capital" that makes this nation the country of birth and persisted until now (Fukuyama, 1995).

Besides discussing how far the paradigm of classical modernism about nationalism still has the basics to be followed, also need to take into account nationalismin anotherperspective. Becausein reality, therearethreefundamental issues that dominate this theory of nation and nationality.

First, ethical and philosophical. This theory that emphasizes theimportance of the nation in human affairs. Whether nation as a destination or to be interpreted together with other values. Or should the nation and national identity as a means to achieve other goals or values.

Second, anthropological and political. This theory has questioned the notion of national boundaries, how nation want to define what to do with the individual with society.

Third, historical and sociological. This approach emphasizes the importance of nation's position in the history of humanity. Historical and cultural bonds become the nation's major adhesive.

Paradigm that emphasizes "the nation and character building", is certainly not wrong in theoretical perspective, let practical pragmatic, but also should not be considered to have absolute truth. As the tradition prevailing in the academic community, what is called a contending theory should be regarded as mandatory match. In thecontext of this nation and national insight, wearefaced with two main paradigms each of which has a strong empirical foundation. First, perennealisme paradigm (nation and character building) a greater emphasis on the political community, modern, created, mechanistic, fragmented, resources, construction of elite and communications base. Second, empirically, contemporary Indonesia is Indonesia that is no longer possible to free himself from the influence of globalization worldwide.

\section{Nationalism Following History Path}

According to Benedict Anderson, a nation is the result of imagination of those who imagine they are in one country and feels the same fate, as well as myths about the past with the glorious. Sense of nationhood or nationalism evolved in the presence of step nationalism spread awareness through a national 
movement spearheaded by the intelligentsia. For example Indonesian students in Holland founded the Association of Indonesia (PI) in 1925, has put its political independence as a primary goal. It can be seen in ideological movements, which can then reinforce the nationalism of Indonesian nationhood, namely : First, national unity, namely the need to put aside narrow differences and differences by region, and is necessary to form a unity of action against the Netherlands to create the State of nationality Indonesia an independent and united. Secondly, solidarity, i.e irrespective of differences that exist among people of Indonesia, it is necessary to realize the existence of a fundamental conflict of interest between the colonizers and the colonized, and the nationalists havetried to sharpen the conflict between white men and brown. Third, non-cooperation, which is imperative to realize that independence rather than a voluntary gift from the Netherlands, but it must be seized by the Indonesian nation itself by relying on its own strengths and abilities, and therefore do not need to heed the colonial legislature as Volksraad. Fourth, self-supporting, i.e, by relying on its own strength (Ingleson, 1983; Gani, 1973; Kartodirdjo, 1992).

Nationalism experience a process in accordance with the times. Every generation has its own view of nationalism. Popularly we can say that nationalism is different in outlook 1908 with the forces of 45, different views of nationalism force 66, thus differing views with force 98 (Fukuyama, 2006).

Nationalism in the present context to young people who care about the future of the nation and the state is concerned the basic right of the people, work hard, study hard, anti-corruption, and maintain unity, as well as having high social concern, but unique with the development of information technology and acceleration motion of the world, Indonesia is currently faced with the challenge of nationhood. Today's communication networks are wide open. Various information presented abundant, in fact rarely end up difficult to choose which ones should be absorbed, and which ones should be abandoned or discarded.

On the other hand, encouraged people in the movement of history or age so fast. Live competition becomes more intense, thus placing the winner's gets all rewards. Citing the idea of Richard Sennett in J oseph Stiglitz (2002) "TheCulture of The New Capitalism," Haryatmako said, it contributes to theloss of the position of the cooperation element, because it focuses on individual skills, and selforiented. Of course, that position seems inconsistent with the idea of nationhood that delivered the founders and initiators of Boedi Oetomo and others of the past century (Kompas, 19 May, 2008 : 34). The characterize of tribute for community and diversity are complete in new culture of capitalism that self-oriented. So what can be done to it? Education. Educational does not bring students to the process of divisions, but the educational value of diversity (multicultural education). Do not we come up with much less stimulating regional and trends exclusivism, but raise the inclusifism attitude (Ricklefs, 2001).

Now after a century later, 65 years Indonesia's independence, this nation was still struggling in the same issue of nationality. Ironically the world is moving so fast, has even spawned a new colonialism, namely the economic and cultural 
colonization (Kompas, 19 May, 2008).

Difficulttoarguethatthehistoryofthisnationisdeterminedbytheinternational political arena. When western carrying the capitalism ideology, dealing with the communist Uni Soviet during the cold war, the fight that led to the struggle for influence in the region, construction of military force, control of natural resources and the world economy (Kahin, 1997). But now the factors of globalization has resulted in the world of international relationships between nations increasingly felt very fast, because the interconnection relationships between nations can easily be done in a very short time, with the help of international communication media (International network).

\section{Nationalism Rise From A Discrepancy}

Experience of history and uncertainty in looking to the future, where a flag World Treaty Organization (WTO) is flying, disturbing sleep soundly prosperous country and disturbing new countries struggling economy pushed the pace. In the political realm, critical reflection on the state and nation in the context of global competition has a place on the agenda of each country, Indonesia is no exception. They were forced back to contemplate itself, its history, and ideals. Nationalism as a theme reappears in connection with many aspects, both economic, political, cultural, educational, and defense. With thenationalism discourse, many emerging pros and cons of power and its relevance to the present, the present attitude of pessimism and optimism.

The term "nationalism" is actually somewhat semantically interpretable, given the widespread use that are referring to different meanings. This term is often associated with the term of nation, nationality and state. But etymologically, shows that nationalism is rooted in the nation and extends on nationality. According to Louis L. Snyder, the term "nationality" is used in the objective meaning or concrete external (national language, region, country, civilization and history) or within the subjective meaning, internal or abstract ideal (national awareness, or sentiment) (Snyder, 1954). To understand more clearly about Indonesian nationalism, needed a historical journey, which means we have to explore nationalism aspects, as well as read its messages.

The idea of nationalism itself is not a very old idea, most do not span the end of the eighteenth century and early nineteenth century, can be used as a reference (Poole, 1993). Although the idea of the state and the nation itself has centuriesold and can be traced far to the thinkers, like Plato and Aristotle, but the building of nationalism discourse beginning in the era of modern thinkers, such as J ohn Locke and Fichte. For this discussion, the nationalism discourse is referring to modern nationalism. In general, nationalism is often associated with the French revolution, industrialization, liberalism, and nation sentiment, which is a classic structure of society that is local and feudal. In conjunction with this sense of nationalism, Slamet Mulyana (2008) said that nationalism is a manifestation of a conscious state or a spirit of nationhood. Nationhood spirit which we understand 
is not independent of national spirit, and that is nationalism.

Historically, the emergence of nationalism left from a classical structure of society which repressive for the people, and favoring certain minority groups (e.g blue blood). In French history, this situation took place during the old regime with the Bastille jail as a symbol of the arbiter's repressively for the people. In those days, the enforcement of feudal law and the rights of ownership of land by blue blood to give a big advantage for blue blood. Throughout XVII century, prices of goods in France rose rapidly along with the rising cost of production. These increases have great benefits, not to farmers (the proletariat), but to landowners wealthy (the bourgeoisie) (Francois, et al, 1989). Things are much different, also occurred in Indonesia, for example by the so-called field state institutions (Kartodirdjo, 1984). This institution originated in the early imperial period and maintained until the mid-XIX century. In 1808, Daendeles remove this system and just take a fifth of the harvest as a land tax, and by Raffless few years later made the land rent as the single land tax. However, it does not mean the whole system is lost, as a privilege for blue blood of the land is still running, even exacerbated by corruption among the civil guardian (Kartodirdjo, 1984).

Theissue of land needs to be elaborated in this paper, since the early discourse of nationalism in real terms is strongly associated with land issues, and became one of the important agenda in the present. Awareness of landless and defend, in the perspective of nationalism became water landless awareness. Water landless essentially water without soil, like a tree without roots, and without a foothold.

French Revolution of 1789 that overthrewLouisXVI, rollingliberalism with the famous motto "liberte", egalite, fraternite. Liberalization project was to develop a view of justice that maintain the subjectivity that leads to goodness (Poole, 1993). The emphasis on rights and individual is central theme of liberalism.

Liberalism has given birth to the capitalist market that should be responsible for liberalism itself. But the capitalist market and the organization of production proved to have paradox, as revealed by Poole.

"The capitalist market and production organization has placed individuals in the network of interdependence wider than that in other forms of society. However, paradoxically, the market and production organization that also serves to separate the individual from consumptive bonds with other individuals. At least in the public world (Poole, 1993).

This of course created a vacuum of values and identity of individuals in front of its sociality. Emptiness of values and individual identity in the modern world manifested in the absurd situation. Albert Camus reflects the French revolution and modernity in The Rebel and came to the conclusion that colonizer have to be done on the absurd situation that, I rebel - therefore I exist (Camus, 1956).

What is required by Camus is a value that unites individuals an intersubjectivity, a social solidarity that transcends individualist. In XVIII century demands that must be answered by a nationalism that is often associated with liberalism in the attractive community in the modern world with the political 
decisions of nation-state.

Nationalism introduce a national identity as self-governance binder and thus the identity of individual to find meaning. National identity is a form of selfawareness, awareness of others as well. That realization identified those who have their identity and that we must help (Poole, 1993).

\section{Nationalism Discourse in the Context of Indonesia}

In Indonesia, nationalism discourse to get its meaning and urgency when there isadebatebetween TjiptoMangoekoesoemoand SoetatmoSoerjokoesoemo. Tjipto established Boedi Oetomo and Indische Partij, whereas Soetatmo established the J avanese Nationalism Committee. The debate was published in 1918 in the form of leaflets titled : J avaansche of Indische Nationalisme "(Kartodirdjo, 1962). Soetatmo promote J ava nationalism which is seen more clearly in the language and cultural foundation for a nation. In this perspective, Soetatmo proposed the role of Pandito as a creator of order in the chaos of the movement to improve relations Kawulo-gusti, people become kawulo sang pandito ratu. Beside him stood Tjipto with Hindia nationalism with theincarnation of true satrio soul, that is moral virtue, through uncompromising opposition to oppression and extortion Netherlands, extortion gentry against the people (Shiraishi. 1986).

This discourse culminates and reaches its climax in the statement of the Youth Pledge October 28, 1928. Youth Pledge had melt out of a narrow view and localism into new way of thinking more broadly, but integrative (Geertz, 1992). Nationalism in 1928 brings together fatherland nationalism, nations and languages as a stepping stone of nationhood movement. Land as a stepping stone is actualized in the thinking of Ross Poole about the state of nationality (Poole, 1993).

Nation-state gives its members belong together that can not be captured, the land where they have the right to life. Nation-state is thus restored the relationship with the land, spatial location and identity, which for most people has been destroyed by the modern world. Fatherland become space dimension in a nation-state and history as time dimensions. The same is expressed Sukarno in a speech to the birth of Pancasila, while laying nationalism as state foundation of Indonesia by emphasizing the unity of people and his place. Can not be separated from the people and the earth under his feet (Nagazumi, 1989).

When theland became the foundation, then thelanguage is the key to national identity are important. Language is a medium to communicate. Every citizen can express certain things with language that is understandable to others and its social, which suggests that community bonds. It should be noted that nationalism itself is not dependent on language, but necessary as a medium for the citizens of a nation. So the language might be an important component of the national existence, but it does not mean the sine qua non (Snyder, 1954).

Is cultural can be identity as nation, as thelanguage? In the same perspective, it seems also true about the culture, but has a different problem contexts and 
broader than the language. Is there a culture that truly singular in the world, so that a community can identify for self with that culture? In fact, culture is more moving in its own process with the intersection of various culture in the world. Most modern state is a nation with multicultural such as Indonesia and the United State. Indonesia is a multicultural country, the integration of each local culture into the national culture is not the imposition of one dominant culture or cultures melting into one form, but let it integrated into the cultural mosaic. So not reasonable to striking the local culture versus national culture, but how do we let the two complement each other, without a rigorous formulation of "national culture, nationalism still exists".

Main things that interfere with the concept of nationalism is the claim of nationalism as an illusion or some sort of "false consciousness" of Marx. Karl Marx claimed that in the state.... (humans) are imaginary members from an imaginary sovereignty, detached from the real life individual, and endowed with an unreal universality (Karl Marx in Poole, 1993).

Faced with such attacks, Benedict Anderson stood at the defense by stating that "nationhood state are imagined because the members of even the smallest nation state will never know most of his fellow members, had never met them, or never even heard of them, but in the minds of each lives the image of their togetherness (Anderson, 1983).

Anderson looked at the nation-state as an imagined community as opposed to fictitious, artificial, or falsity. Nation-state is a product of imagination, but a creative imagination in the trajectory of history.

In line with Anderson, Mochtar Pabottinggi ask two things to defend Indonesia nationalism. First, Indonesia was born not from a delusion so long but of creative imagination and courage of the founders and pioneers of the nation. Second, the pioneers and founders of the nation has inspired the people who neglected to develop their imagination in a deadly climate of the imagination (Pabottinggi, 1993).

The statement of Pabottinggi above is true, but he seems to emphasize the role of the intellectual actors in the formation of Indonesian nationalism. With respect to the nation intellectual, we should also remember that nationalism not be established without a "small pillars" called the people. People sovereignty exists only when people realize and admit it.

One obvious fact, which can not be denied is Indonesia revolution has been involved Indonesian to participate in politics totally. Even just the awareness factor of nationalism that could be used to explain why the mobilization level and people participation so powerful in the revolution, to be willing to hammer the struggle. Surely nationalism, can not simply be rhetoric. Nationalism is loaded with value. He gave the sense, show the way, and became a justification tool for a revolutionary movement. But why today many people who doubt nationalism, especially in the context of globalization, to the term "post-nationalism". Does the term was born as an intellectual turmoil or truly is futuristic ? Clifford Geertz's view, there is a pathological tendency in modern society, when nationalism was appointed to the level of political supremacy. In levels increased, national unity is 
maintained not by shouting to the area and the land, but with a vague allegiance, arising sink, and routine in a civil state, which comes more or less with the use of police forces and the government's ideological insistence, thus Geertz (1992).

Is nationalism has lost its power, because of ideological and enforced ? may be more accurate to say that nationalism has been contaminated by a variety of interests outside of nationalism itself, that is, when he lived a mere political rhetoric with historical arguments, so it closes itself to bearticulated in the present context. Nationalism trapped in the history and pessimistically considered past romantic (Kartodirdjo, 1967).

Your country has been independent, but do you also have an independent nation? Or our state is already independent, but whether we as citizens also have an independent nation? This is the real question of the meaning of nationalism. Not the least of nationalism still exists, but on "independence" that accompanies the spirit of nationalism itself. What was fought for the people of Indonesia first, is self independence, sovereignty itself in the midst of the nations in the world. Nationalism is motive and justification of Indonesian revolution. The independence is a goal. Independence from all forms of oppression.

Thus, it is understood that the doubts about nationalism, not a rejection. $\mathrm{He}$ is a self-criticism against to the nation sovereignty and the ideals of Youth Pledge October 28, 1928, and the Proclamation of Independence August 17, 1945. This critics wanted to open the "nationalism falseness" which only stops at the level of formal history books in schools and speech preamble. Nationalism is not just orthodoxy, but it must be transformed into orthopraxis. Revitalization and realization of nationalism is the locus from nationalism discourse itself.

Indonesia has been an independent country, it obviously can not be denied. Does Indonesia have been independent ? State and nationality are not the same. Nation-state is always based on nationality, but nationality can exist without state (Pabottinggi, 1993). Nationalism preceded the nation, as the Youth Pledge in 1928 preceded the Declaration of Independence 1945. Is not the Constitution of 1945 affirms that (Proclamation) to deliver the people of independent Indonesia, united, sovereign, just and prosperous ? Of course this is not the recording of events, but the ideals of nationalism are again emphasized. Nationalism should weaffirmed. Nationalism should we put it back on the main track, drivingtowards independence.

Nationalism is the enlightenment that relies on the accumulation of actual experience. Are we free when the eviction is still occur and the press and communications media silenced ? are we independent, when it still belonged to the meaning of language, and education was not intellectual ? Are we prosperous, whilepoverty isstill rampant in theland of our own ancestors? areweindependent, when social and political inequalities are still so far away? Are we independent, when there is no guarantee of legal protection and justice ? are we independent, when world's economic systems cornered of developing countries ? And many dreams of this kind continue with the swift flow of country boy's dream, as if glorified back what is voiced by our intellectuals in the past.

Indonesian nationalism, not a narrow nationalism that defends the nation for 
whatever reason. "right or wrong is my-country" is exaggerated sentiment of the nation can bear fruit racism and rape of humanity and truth. Our nationalism is not merely serve the political form of state per se, but rather on the nation, the fate of the people in it. Thus, humanity is his rasper, and goodliness is the basis. Nationalism is not dead, not faded, he remained alive in the hearts of the people of Indonesia, including its youth.

In the context of modern Indonesia today, there are three rules that must be the foundation in building our great Indonesia, namely: First, father land or land without oppression. Secondly, nation are infatuated for justice, and Third, one speech that is truth language.

Three main points that emerged, without oppression, justice, and truth are nationalism discourses today, which presents a critical re-calls the nation's forefathers. It's true, that the young generation now, not experienced colonialism and revolution, but it is naive to say that they can not empathize with that experience and deprived of nationalism. The past is the past remain. Now is now. But the experience of nationalism before is showed in the present, although different in form and structure. The struggle over the ideals of nationalism has not stopped, but was greeted by the current generation to continue.

If theindependencewar, thespirit of Indonesian nationalism fueled by thefight against oppression and injustice committed by colonizer for people of Indonesia, the main points that can be underlined, which then become the spirit as well as trigger the resistance against the colonial government, is there is discrepancy between colonizer group (European) with the indigenous people (Nagazwni, 1986), the Indonesian nationalism today must be interpreted as a spirit to fight the various discrepancy, which include economic disparities, political, legal, and cultural between developed countries and all its instruments free market (IMF, WTO and World Bank) that sucks and make profits from developing countries. In the context of nation and state life, the discrepancies is widening between the wealthy class that gets most of its prosperity from sucking the small people.

\section{Conclusion}

From the discussion above, it can be concluded that in historical perspective, actually nationalism has emerged and grown significantly in the collective awareness of Indonesia nation since the birth of Boedi Octomo May 20, 1998 and confirmed again through the Youth Pledge October 28, 1928. Collective awareness of nationalism was becoming crystallized, when consciously and courageously Indonesia proclaimed independence on August 17, 1945. Strength grew steely sense of nationhood, precisely when the Indonesian nation to defend themselves from undermining the attempt was about to remove a sense of nationhood after the proclamation of independence.

From philosophical perspective, in nationalism discourses, collective awareness that is owned by founding father, tend to nationalism rooted in the principle of multicultural (Bhineka tunggal ika) as a basis for the nation's natural 
diversity. This principle does not once occur to it forever, but experienced a period of up and down, in line with the dynamics of history. If at the time before, the early and post-independence the principles of nationality was actualized in the attitude and assertiveness are real, then when Indonesia is doing physical and economic development, emerging uncertainty and a number of deviations on these principles. This happens because during the New Order government, states using the military approach as a medium to unite the nation. This approach will resolve the territorial integrity only physically, but the spirit of nationalism can never be established through violence. Therefore it is no wonder, if we see a lot of resentment arise prolonged history in this country, in the form of separatist movements, who want to secede from the Unitary Republic of Indonesia, because the approach used by the government in fostering nationalism is the approach of military violence, whereas in Indonesia a multicultural, the most appropriate approach in an attempt to resolve any issues of culture or nationality is a cultural approach.

Important meaning behind every historical event is how we are able to reap the wisdom behind the historical events that happened. Especially, meaning of nationalism in the context of Indonesian history today is how to interpret nationalism as soul and spirit to oppose poverty, injustice, slavery, tyranny, oppression and backwardness. How can this nation be able to resolve conflicts between regions against the background elements of SARA.

Nationalism was not born to carry theinterest of a race, religion or a particular region, but for something imagined. Imagined is the equation of kinship to maintain the integrity and unity to live together in a nation state that aspired.

Freedom imagination has tremendous strength in moving the minds and actions of the founders to oppose again colonialism and neocolonialism which threaten the existence of the state and nation.

Now the past imagination, needs to be raised again to motivate and inspire citizensin opposinginjustice, poverty, backwardness, opposethenewcolonialism, in the form of economic and cultural exploitation by developed countries against developing countries, like Indonesia.

By understanding and interpret the history of the past, is expected in the future no longer heard the demands of a group of local citizens who want to secede from the Unitary Republic of Indonesia. Will not show any conflicts or wars between tribes, villages, schools and others, because everyone was familiar and interpret that Indonesia is one, we are brothers.

With a historical memory will togetherness, hopefully we'll not only get the correct structure of collective memory, but also an inspiring historical wisdom. Is not without understanding history creatively, nationalism can never be born. 


\section{REFERENCES}

Abdul Gani, R. (1973). Nationalism, Revolution, and Guided Democracy in Indonesia. Monash University: Clayton VIC of Southeast Asian Studies.

Anderson, B. (1983). Imagined Communities : Reflections on the Origin and Spread of Nationalism. London : Verso.

Camus, A. (1956). The Rebel. An Essay on Man in Revolt. USA: NewYork Vintage Book.

Corver, A.F.E. (1985). Islamic Union : Fair Queen Movement? J akarta : Grafiti Pers.

Desai, S. (1989). Southeast Asia, Past and Present, New York: Macmillan.

Dahm, B. (1987). Soekarno and the Struggle for Independence, Jakarta : LP3ES.

D. Smith, A. (1998). Nationalism and Modernism, New York: Routledge.

Fukuyama, F. (1995). Trust : The Social Virtues and The Creation of Prosperity, New York: The Free Press.

Furet, F. (1989). French Revolution. Yogyakarta : Gadjah Mada University Press.

Faisal Bakti, A. (2006). Nation Building. J akarta : Churia Press.

Geertz, C. (1992). Culture Political : Yogyakarta : Kanisius

Hanifah, Abu. (1978). Reflection of Nation Struggle Past and Present, J akarta : Press Idayu Foundation .

Hardianto, B. J.S. (2008). Inspiration from Sorrow Towards the Nation, in Kompas. May 19, 2008, p.34.

H. Frederick, W, et. Al. (1991). Understanding of Indonesia's History before and After Revolution, J akarta : LP3ES.

Ingleson. J . (1983). Road to Exile : The National Movement of Indonesia 19271934, J akarta: LP3ES.

Kahin, A. R. (1997). Subversion as Foreign Policy, New York: Yale University Press.

Kahin, G. McT. (1952). Nationalism and Revolution in Indonesia. Ithaca: N.Y Cornell University Press.

Kartodirdjo, S. (1962). SomeProblems on theGenesis of Nationalismin Indonesia J SAH, 3.1 (March) 1962.

Kartodirdjo, S. (1967), Colonialism and Nationalism XIX-XX Century, History Sheet, Yogyakarta : Research Section, Department of History, Faculty of Letters and Cultural, Gadjah Mada University No.1.

Kartodirdjo, S. (1984). Uprising Banten's Farmers in 1888 : Conditions, Events Path, and Continuance (A Case Study About Social Movement in Indonesia), 
Jakarta : Pustaka J aya.

Kartodirdjo, S. (1992). Introduction to the New Indonesia History : History of National Movement From Colonialism until Nationalism (2). Jakarta : Gramedia Pustaka Utama.

Luhulima, J . (2008). The spirit of Nationality Should Continue Maintained, in Kompas, May 19, 2008, p.1 and 15.

Madjid, N. (1998). Finding Roots of Modern Pluralism. The Experience of Indonesia, in Mark R. Wood (ed) New Way of Islam, Bandung : Mizan

Moedjanto, G. (1988). The 20th century Indonesia : From National Awakening until Linggajati (1), Yogyakarta: LKiS.

Mulyana, S. (2008). National Awareness From Colonialism to Independence (1), Yogyakarta: LKiS.

Nagazumi, A. (1986). Indonesia In Study Japanese's Scholar: Socio-economic Change in XIX-XX Centuries and Various Aspects of Indonesia Nationalism, Jakarta : Obor Institute.

Nagazumi, A. (1989). The Dawn of Indonesian Nationalism : The Early Years of the Budi Utomo, 1908-1918, J akarta : Obor Institute.

Noer, D. (1980). Modern Islamic Movement in Indonesia 1900-1942. Jakarta: LP3ES.

Notosusanto, N. (1992). National History of Indonesia 3.J akarta : MOEC.

Onghokham. (1984). Keepsake of Doctor Soetomo, J akarta : Sinar Harapan.

Book Committee. (1984). One Hundred Years of Agussalim (A Biography), J akarta : Sinar Harapan.

Prastiti Scherer, S. (1985). Alignment and Gaffe. Thoughts of J ava Nationalist Indigenous in Early XX Century. J akarta : Sinar Agape Press.

Pringgodigdo, A.K. (1986). History of Indonesian People's Movement. J akarta : Dian Rakyat.

Poole, R. (1993). Morality and Modernity in the Shadows of Militarism. Yogyakarta : Canisius.

Pabotinggi, M. (1993), Spot Our Nationalism. J akarta : LP3ES.

Poespoprodjo, W. (1982). Traces of History The Form of a Pattern, Jakarta : LP3ES.

Ricklefs, MC. (1999). Modern History of Indonesia. Yogyakarta: Gadjah Mada University Press.

Riyanto CM, F. (2008). Sense of Nationality of 1928, in Compass October 27, 2008, p.6.

S. Truna, D, et.al. (2002). Islamic institutions in Indonesia : Social Struggle, Politics, Law and Education. J akarta : Logos Wacana Ilmu.

Snyder, L. L. (1954). The Meaning of Nationalism. NewJ ersey: Rutgers University Press. 
Suhartono. (1994). History of National Movement From Budi Utomo until Proclamation 1908-1945. Yogyakarta : Pustaka Pelajar.

Shiraishi, T. (1986). Chevalier Vs Pandita : A Debate In Search of Identity, in Akira Nagazumi (eds) Indonesia in J apanese Scholar Study. J akarta : Obor Indonesia Institute.

Stiglitz, J. (2002). Globalization and its Discontent. Jakarta : Kompas Publisher

Van Niel, R. (1984). The Emergence of the Modern Indonesian Elite. J akarta : Pustaka Jaya.

Wild, C, et. al. (1986). The Fire Surge of Revolution. An Anthology of History, Jakarta : Gramedia. 